\title{
Growth performance, nutrient utilization, and feed efficiency in broilers fed Tithonia diversifolia leaf meal as substitute of conventional feed ingredients in Mizoram
}

\author{
Rajat Buragohain \\ Department of Animal Nutrition, College of Veterinary Sciences and Animal Husbandry, Central Agricultural University, \\ Selesih, Aizawl, Mizoram, India. \\ Corresponding author: Rajat Buragohain, e-mail: drrajat57@gmail.com \\ Received: 14-10-2015, Accepted: 28-03-2016, Published online: 06-05-2016
}

doi: 10.14202/vetworld.2016.444-449 How to cite this article: Buragohain R (2016) Growth performance, nutrient utilization, and feed efficiency in broilers fed Tithonia diversifolia leaf meal as substitute of conventional feed ingredients in Mizoram, Veterinary World, 9(5): 444-449.

\begin{abstract}
Aim: The study was for assessment of growth performance, nutrient utilization, and feed efficiency in broilers fed rations with varying levels of Tithonia diversifolia leaf meal (TDLM) as a substitute of conventional feed ingredients in Mizoram.

Materials and Methods: A total of 180, 1-day-old broiler chicks were randomly divided into six homogeneous groups and fed rations incorporated with TDLM (TDLM at 0\% [TDLM-0], 2\% [TDLM-2], 4\% [TDLM-4], 6\% [TDLM-6], 8\% [TDLM-8], and 10\% [TDLM-10] level as substitute of conventional feed ingredients) for 6 weeks. The chicks were reared in battery brooders for the first 2 weeks, and thereafter, in well-ventilated deep litter house following standard management protocols. Feed and drinking water were provided ad libitum to all the groups throughout the experiment. The daily feed intake and weekly body weight gain were recorded, and a metabolic trial for 3 days was conducted at the end of the $6^{\text {th }}$ week.

Results: Feed consumption decreased for inclusion of TDLM but without any significant differences, except during the $3^{\text {rd }}$ week where it reduced significantly $(\mathrm{p}<0.05)$ at and above $6 \%$ TDLM in the ration. The average body weight gain decreased significantly $(\mathrm{p}<0.05)$ above $6 \%$ TDLM inclusion. The average body weights at $7^{\text {th }}, 14^{\text {th }}$, and $21^{\text {st }}$ day of age reduced significantly $(\mathrm{p}<0.05)$ from $4 \%$ to $10 \%$ TDLM inclusion level but was statistically non-significant up to 4\% TDLM at $28^{\text {th }}, 35^{\text {th }}$, and $42^{\text {nd }}$ day of age. Body weight at $42^{\text {nd }}$ day of age was $1624.72 \pm 30.52,1616.66 \pm 17.84,1592.60 \pm 19.24$, 1404.61 $\pm 17.76,1188.29 \pm 17.67$, and 1054.33 \pm 18.81 gin TDLM-0, TDLM-2, TDLM-4, TDLM-6, TDLM-8, and TDLM-10, respectively. The digestibility of nutrients decreased with increased inclusion level of TDLM. The digestibility coefficient of dry matter, crude protein, ether extract, and nitrogen free extract were significantly higher in TDLM-0, but crude fiber digestibility was comparable without any significant difference among the groups. Feed conversion ratio (FCR) at $42^{\text {nd }}$ day of age was $2.17 \pm 0.15,2.17 \pm 0.15,2.13 \pm 0.13,2.46 \pm 0.16,2.66 \pm 0.11$, and $3.96 \pm 0.10$ for TDLM-0, TDLM-2, TDLM-4, TDLM-6, TDLM-8, and TDLM-10, respectively, was statistically non-significant up to 4\% TDLM inclusion level.

Conclusion: Considering the insignificant effects on growth rate, FCR, and body weight at $42^{\text {nd }}$ day of age, it was concluded that TDLM could be incorporated up to $4 \%$ level as substitute of the conventional feed ingredients for broilers reared under deep litter system of management in Mizoram.
\end{abstract}

Keywords: broiler, growth, Mizoram, nutrient digestibility, Tithonia diversifolia leaf meal.

\section{Introduction}

Broiler farming is a popular economic activity throughout Mizoram for the tremendous demand of its meat in the state. The broiler is sold at Rs. 170200/kg live weight and Rs. 250-280/kg dressed weight (Market price during 2014-2015) in local markets of Aizawl city, and the price is increasing day by day.

Feeding alone accounts for $60-80 \%$ of the total production cost of broiler enterprise. This factor has been the main hindrance for broiler farmers in Mizoram toward achieving the expected monetary returns from their enterprises. The cost of both broiler

Copyright: Buragohain. Open Access. This article is distributed under the terms of the Creative Commons Attribution 4.0 International License (http://creativecommons.org/licenses/by/4.0/), which permits unrestricted use, distribution, and reproduction in any medium, provided you give appropriate credit to the original author(s) and the source, provide a link to the Creative Commons license, and indicate if changes were made. The Creative Commons Public Domain Dedication waiver (http://creativecommons.org/ publicdomain/zero/1.0/) applies to the data made available in this article, unless otherwise stated. commercial feed mixture and feed ingredients is high in Mizoram as compared to other states of the mainland. It is because of geographical constraints resulting in deficit production of food grains, and hilly terrains causing higher transportation cost and hence the prices of the commodities. To ensure remunerative return to broiler farmers in Mizoram, it has become imperative to search for alternative feed resources which do not have competition with human being for consumption to reduce the feeding cost of broilers.

Utilization of unconventional local feeds as substitutes of conventional ones is a popular trend in broiler feeding practices [1-4]. Depending on availability and nutritional values, many unconventional feeds are used in broiler rations to economize the feeding. In Mizoram, Tithonia diversifolia, i.e., wild sunflower may be one such promising unconventional feed as it is abundantly available throughout Mizoram and is a good source of protein and rich in other nutrients [5]. Wild sunflower or Mexican sunflower, 
also known as tree marigold, belongs to family "Asteraceae" and botanical name is T. diversifolia (Hemsl.) A. Gray. In Mizoram, it is locally called as Bawng-pu-pang-par or Vai-va-kawn-par. It is a large shrub with 3-5 lobed leaves and yellowish orange flowers. It grows well at altitude $800-1500 \mathrm{~m}$ and flowering season is November and December month of every year. The flower heads are used in wounds and bruises. The plant is also used as remedy against malaria, jaundice, hepatitis, liver problems, intestinal parasites, sore throat, etc. The leaves are sometimes collected for cattle fodder and also cooked with other leaves for pig's feed [6]. The leaves of $T$. diversifolia are good sources of nutrients, particularly protein, energy, and mineral matters. It has $22.47 \pm 0.34 \%$ dry matter (DM), and $25.07 \pm 0.00 \%$ crude protein $(\mathrm{CP})$, $2.19 \pm 0.00 \%$ ether extract (EE), $9.51 \pm 0.01 \%$ total ash (TA), and $4223 \pm 4.04 \mathrm{kcal}$ GE $/ \mathrm{kg}$ on DM basis [7]. It contains $1.72 \pm 0.02 \%$ calcium, $0.17 \pm 0.00 \%$ total phosphorous, $0.12 \pm 0.00 \mathrm{ppm}$ copper, $0.87 \pm 0.03 \mathrm{ppm}$ iron, and $1.66 \pm 0.05 \mathrm{ppm}$ manganese. The acid detergent lignin, total tannins, and condensed tannins of TDLM are $7.93 \pm 0.39 \%, \quad 5.79 \pm 0.26 \%$, and $0.23 \pm 0.01 \%$, respectively [8].

Considerable information is available about utilization of TDLM for broiler feeding in other parts of the world $[9,10]$, but no report is available about its utilization as broiler feed substitute in Mizoram and rest of Indian subcontinent. The findings generated in other parts of the world may not be directly applicable to the farmers of Mizoram, and India as a whole, for differences in altitudes and agro-climatic conditions. Therefore, in this study, an attempt was made to evaluate the effects of feeding $T$. diversifolia leaf meal (TDLM) on growth performance, nutrient utilization and feed efficiency of broilers reared under deep litter system of management in Mizoram.

\section{Materials and Methods}

\section{Ethical approval}

The necessary approval was taken from Institutional Animal Ethics Committee (Approval reference number-CVSC/CAU/IAEC/11-12/P2) for conducting the study.

\section{Location of the study}

The study was carried out at the poultry unit of Instructional Livestock Farm Complex (ILFC), College of Veterinary Sciences and Animal Husbandry, Central Agricultural University, Selesih, Aizawl, Mizoram, India.

\section{Collection of $\boldsymbol{T}$. diversifolia leaves and preparation of leaf meal}

The wild sunflower ( $T$. diversifolia) plants were collected from different locations in and around the College of Veterinary Sciences and Animal Husbandry, Central Agricultural University, Aizawl, Mizoram. The leaves of different developmental stages were separated from stems, pooled together and sun-dried until the leaves become crispy while still retaining the greenish coloration. The dried leaves were then milled using a hammer grinding machine to produce leaf meal and stored in airtight condition until utilization (Figure-1).

\section{Experimental birds and design of experiment}

A total of 180, 1-day-old broiler chicks were purchased from retailer of Aizawl city, Mizoram, India. The chicks were randomly divided into six homogeneous groups with 30 chicks in each group in a completely randomized design. Each group had three replicates of 10 chicks in each. The experimental groups were designated as TDLM-0, TDLM-2, TDLM-4, TDLM-6, TDLM-8, and TDLM-10. The birds were wing-banded for easy identification.

\section{Ration formulation and feeding management}

Isocaloric and isonitrogenous broiler starter and finisher rations were formulated (Table-1) following the recommendations of BIS [11]. Starter ration was fed up to $35^{\text {th }}$ day of age and finisher ration, thereafter, was up to $42^{\text {nd }}$ day of age. The TDLM was incorporated in starter and finisher rations at 0\% (TDLM-0), 2\% (TDLM-2), 4\% (TDLM-4), 6\% (TDLM-6), 8\% (TDLM-8), and 10\% (TDLM-10) level of the total ration. The quantities of conventional ingredients (yellow maize, rice polish, soybean meal, and groundnut cake) were adjusted to balance the rations.

The feed was provided ad libitum to the experimental birds and drinking water was made available throughout the day. The chicks were reared in battery brooder during the first 2 weeks of their life and afterward housed in well-ventilated deep litter house partitioning into 18 hens providing required floor space $(1.5 \mathrm{ft} \times 1.5 \mathrm{ft} /$ bird $)$. Rice husk was utilized as litter material. The birds were vaccinated against new castle disease (Lasota) on the $7^{\text {th }}$ day and against infectious bursal disease on the $14^{\text {th }}$ day of age. The strict biosecurity measures were followed during the experiment.

\section{Duration of experiment and details of records made}

The feeding trial was conducted for 6 weeks. The total amounts of feed offered and residue left within $24 \mathrm{~h}$ were recorded daily for calculation of average daily feed intake. The individual body weights were taken at weekly interval. Mortality record was made, and post-mortem examination was carried out to find out the probable cause of death.

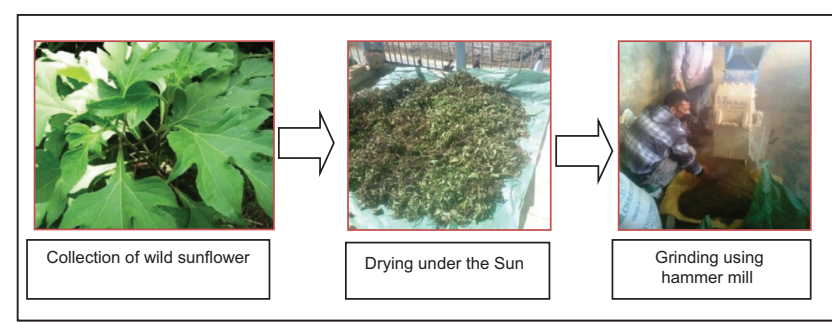

Figure-1: Steps involved in preparation of Tithonia diversifolia leaf meal. 


\section{Metabolic trial}

At the end of $6^{\text {th }}$ week, a metabolic trial for 3 days was conducted. Two birds from each replicate, i.e., six birds from each treatment were randomly selected for the trial. The feed offered and residue left within $24 \mathrm{~h}$ was recorded to estimate daily feed intake. Feces voided within $24 \mathrm{~h}$ were collected and weighed. A definite proportion of feces (i.e. $1 / 20^{\text {th }}$ part) after thorough mixing was kept in glass petridish and placed in hot air oven at $100 \pm 1{ }^{\circ} \mathrm{C}$ overnight for determination of DM. Another sample, $1 / 30^{\text {th }}$ part of feces, was weighed and preserved in 1:4 $\mathrm{H}_{2} \mathrm{SO}_{4}$ for determination of nitrogen. After 3 days of collection, the pooled samples of feces were mixed thoroughly and a suitable amount of undried preserved samples was weighed in duplicate for determination of nitrogen. The dried sample after grinding was utilized for estimation of other proximate principles.

\section{Chemical assay}

The rations, residual feeds, and feces voided during the metabolic trial were analyzed for DM, crude fiber (CF), EE, nitrogen free extract (NFE) and TA following methods of AOAC [12] and nitrogen for $\mathrm{CP}$ estimation by Kjeldahl method. The calcium and phosphorous were estimated as per methods of Talapatra et al. [13].The micro minerals were analyzed in atomic absorption spectrophotometer (GBC) following standard protocols. The tannin was estimated as tannic acid equivalent using Folin-Ciocalteu reagent method [14] and condensed tannin as leucocyanidin equivalents following method of Porter et al. [15].

\section{Statistical analysis}

The generated data were subjected to analysis of variance following statistical methods of Snedecor and Cochran [16].

\section{Results and Discussion}

\section{Feed consumption}

Feed is the most costly expense in broiler production involving $60-80 \%$ of the total production cost. Thus, the feed efficiency is typically the primary tool by which performance of a broiler flock is evaluated. The average daily feed intake of broilers fed TDLM is presented in Table-2. Daily feed intake decreased with increased inclusion level of TDLM in the ration. However, no significant difference $(p>0.05)$ was observed among the groups in average daily feed intake except during the $3^{\text {rd }}$ week of age. Decreasing trend of feed consumption might be for increasing CF levels with increased level of TDLM in the ration resulting bulkiness thereby reducing feed consumption. Similar findings were also reported by Ekeocha [9] for broiler. Odunsi et al. [17] reported that broiler finishers fed wild sunflower leaf meal showed depressed feed intake most especially at 7.5 and $10.0 \%$ inclusion level. Decreased feed intake might also be for anti-nutritional factors present in TDLM, particularly tannin

Table-1: Ingredient $(\mathrm{kg})$ and nutritional composition (\% on DM basis) of the experimental rations with TDLM.

\begin{tabular}{|c|c|c|c|c|c|c|c|c|c|c|c|c|}
\hline \multirow[t]{2}{*}{ Ingredient } & \multicolumn{2}{|c|}{ TDLM-0 } & \multicolumn{2}{|c|}{ TDLM-2 } & \multicolumn{2}{|c|}{ TDLM-4 } & \multicolumn{2}{|c|}{ TDLM-6 } & \multicolumn{2}{|c|}{ TDLM-8 } & \multicolumn{2}{|c|}{ TDLM-10 } \\
\hline & BS & BF & BS & BF & BS & BF & BS & BF & BS & BF & BS & BF \\
\hline \multicolumn{13}{|c|}{ Ingredient composition } \\
\hline YM & 52 & 57 & 52 & 57 & 52 & 56 & 51 & 56 & 50 & 56 & 50 & 55 \\
\hline $\mathrm{RP}$ & 10 & 13 & 9 & 12 & 9 & 12 & 9 & 11 & 9 & 10 & 8 & 10 \\
\hline SBM (SE) & 20 & 15 & 20 & 14 & 18 & 13 & 17 & 13 & 16 & 12 & 16 & 12 \\
\hline GNC (SE) & 10 & 8 & 9 & 8 & 9 & 8 & 9 & 7 & 9 & 7 & 8 & 6 \\
\hline FM & 6 & 5 & 6 & 5 & 6 & 5 & 6 & 5 & 6 & 5 & 6 & 5 \\
\hline TDLM & 0 & 0 & 2 & 2 & 4 & 4 & 6 & 6 & 8 & 8 & 10 & 10 \\
\hline $\mathrm{FA} / \mathrm{MM} *$ & 1.8 & 1.8 & 1.8 & 1.8 & 1.8 & 1.8 & 1.8 & 1.8 & 1.8 & 1.8 & 1.8 & 1.8 \\
\hline Salt & 0.2 & 0.2 & 0.2 & 0.2 & 0.2 & 0.2 & 0.2 & 0.2 & 0.2 & 0.2 & 0.2 & 0.2 \\
\hline Total & 100 & 100 & 100 & 100 & 100 & 100 & 100 & 100 & 100 & 100 & 100 & 100 \\
\hline \multicolumn{13}{|c|}{$\begin{array}{l}\text { Nutritional composition } \\
\text { (\% on DM basis) }\end{array}$} \\
\hline DM & 91.65 & 91.18 & 91.17 & 91.2 & 91.26 & 88.79 & 91.18 & 90.84 & 91.35 & 91.08 & 91.38 & 91.13 \\
\hline $\mathrm{CP}$ & 23.58 & 20.68 & 23.41 & 20.49 & 23.3 & 20.52 & 23.26 & 20.35 & 23.2 & 20.26 & 23.05 & 20.2 \\
\hline EE & 3.88 & 4.37 & 3.77 & 4.3 & 3.8 & 4.32 & 3.81 & 4.24 & 3.81 & 4.17 & 3.71 & 4.19 \\
\hline $\mathrm{CF}$ & 4.2 & 4.2 & 4.32 & 4.33 & 4.48 & 4.62 & 4.69 & 4.78 & 5.15 & 5.02 & 5.2 & 5.2 \\
\hline $\mathrm{TA}$ & 13.06 & 10.05 & 12.55 & 11.14 & 12.34 & 10.74 & 11.94 & 10.17 & 12.99 & 11.46 & 11.32 & 11.7 \\
\hline NFE & 55.28 & 60.7 & 55.95 & 59.74 & 56.08 & 59.8 & 56.3 & 60.46 & 54.85 & 59.09 & 56.72 & 58.71 \\
\hline ME & 2879 & 2939 & 2874.1 & 2931.6 & 2870.4 & 2921.2 & 2860 & 2916.3 & 2849.9 & 2908.9 & 2845 & 2901 \\
\hline $\mathrm{Ca}$ & 0.96 & 0.87 & 0.99 & 0.89 & 1.02 & 0.93 & 1.05 & 0.95 & 1.09 & 0.99 & 1.11 & 1.01 \\
\hline$A P$ & 0.48 & 0.45 & 0.48 & 0.44 & 0.47 & 0.44 & 0.47 & 0.44 & 0.46 & 0.42 & 0.46 & 0.41 \\
\hline $\mathrm{L}$ & 1.39 & 1.2 & 1.37 & 1.16 & 1.29 & 1.12 & 1.25 & 1.07 & 1.21 & 1.03 & 1.2 & 1.02 \\
\hline$M$ & 0.64 & 0.6 & 0.63 & 0.59 & 0.62 & 0.58 & 0.61 & 0.57 & 0.6 & 0.56 & 0.59 & 0.56 \\
\hline
\end{tabular}

$\mathrm{BS}=$ Broiler starter, $\mathrm{BF}=$ Broiler finisher, $\mathrm{YM}=$ Yellow maize, $\mathrm{RP}=$ Rice polish, SBM (SE)=Soyabean meal (solvent extracted), GNC (SE)=Ground nut cake (solvent extracted), FM=Fish meal, FA/MM=Feed additives/mineral mixture. *Feed additives/mineral mixture: $\mathrm{TCP}=1.0 \%$, trace mineral mixture $=0.4 \%$, Vitamin mixture $=0.2 \%$, Lysine $=0.05 \%$, Methionine $=0.15 \%$. DM $=$ Dry matter, $\mathrm{CP}=$ Crude protein, $\mathrm{EE}=$ Ether extract, $\mathrm{CF}=$ Crude fiber, $\mathrm{TA}=$ Total ash, NFE=Nitrogen free extract, $\mathrm{ME}=$ Calculated value in $\mathrm{kcal} / \mathrm{kg}, \mathrm{Ca}=$ Calcium, $\mathrm{AP}=$ Available phosphorous, $\mathrm{L}=\mathrm{Lysine}, \mathrm{M}=$ Methionine, Quantity of Micro-mineral added: $0.4 \mathrm{~kg} / 100 \mathrm{~kg}$ feed mixture, Quantity of vitamins added=0.2 kg/100 kg feed mixture, $\mathrm{TCP}=$ Tricalcium phosphate, TDLM=Tithonia diversifolia leaf meal 
that consequently made rations bitter as it increased across treatments [9].

\section{Growth performance of broilers}

The average daily gain in body weight decreased with increased inclusion level of TDLM in the ration (Table-3). However, the growth rate was comparable up to $4 \%$ inclusion level without any significant difference, but reduced significantly $(\mathrm{p}<0.05)$ at and above $6 \%$ level of TDLM. Togun et al. [18] reported that live and carcass weight of broilers were reduced significantly by wild sunflower forage meal inclusion above $10 \%$ level in the ration. Similarly, Bolu et al. [4] also observed reduced growth rate in broilers when fed dried pawpaw seed above 5\% level in the ration. The poor growth performance of the birds with higher inclusion levels of TDLM might be for accumulative or chronic effects of the anti-nutritional factors present in TDLM.

The average body weight at $42^{\text {nd }}$ day of age was recorded as $1624.72 \pm 30.52,1596.66 \pm 17.84$, $1592.60 \pm 19.24, \quad 1404.61 \pm 17.76, \quad 1188.29 \pm 17.67$, $1054.33 \pm 18.81 \mathrm{~g} / \mathrm{bird}$, respectively, for TDLM-0, TDLM-2, TDLM-4, TDLM-6, TDLM-8, and TDLM-10 (Table-4). The average body weights of TDLM-0 and TDLM-2were significantly higher $(p<0.05)$ than other groups up to $21^{\text {st }}$ day of age, but from $28^{\text {th }}$ day onward, no significant difference ( $p>0.05$ ) was observed among between TDLM-0, TDLM-2, and TDLM-4 and was significantly $(\mathrm{p}<0.05)$ higher than TDLM-6, TDLM-8, and TDLM-10. This might be for depressed feed acceptability and consequently nutrient intake [19] for high fiber and bulkiness of feed mixture in TDLM-6, TDLM-8, and TDLM-10. Similar findings were also reported by Akinmutimi et al. [20] for sword bean (Canavalia gladiata) and Obun et al. [21] for Detarium microcarpum seed meal in broilers.

\section{Digestibility of nutrients}

Apparent digestibility of nutrients (Table-5) decreased for the inclusion of TDLM in the ration. The digestibility coefficient of CP, EE, CF, and NFE ranged from $53.51 \pm 2.12 \%$ to $65.89 \pm 0.05 \%, 49.46 \pm 1.21 \%$ to $61.40 \pm 0.49 \%, 42.98 \pm 2.71 \%$ to $43.92 \pm 3.40 \%$, and $69.36 \pm 2.41 \%$ to $82.09 \pm 0.51 \%$, respectively. The decreasing trend of digestibility in TDLM included groups might be for high CF contents and anti-nutritional factors of TDLM. Tannin can bind dietary proteins and digestive enzymes into complexes which are not readily digestible. It can also bind with the proteins of saliva and mucosal membranes [22]. However, no significant differences $(\mathrm{p}>0.05)$ were observed among groups in CF digestibility but was in decreasing trend.

Table-2: Average daily feed intake (g/bird/day) in broilers fed TDLM.

\begin{tabular}{lcccccc}
\hline Age & TDLM-0 & TDLM-2 & TDLM-4 & TDLM-6 & TDLM-8 \\
\hline $1^{\text {st }}$ & $18.03 \pm 2.00$ & $16.99 \pm 1.86$ & $16.41 \pm 2.36$ & $15.80 \pm 2.20$ & $15.44 \pm 2.16$ \\
$2^{\text {nd }}$ & $42.37 \pm 4.74$ & $41.07 \pm 4.13$ & $40.49 \pm 4.34$ & $40.70 \pm 4.59$ & $36.26 \pm 3.38$ & $34.88 \pm 4.10$ \\
$3^{\text {rd }}$ & $63.12 \pm 2.96^{\mathrm{a}}$ & $61.16 \pm 3.05^{\mathrm{abc}}$ & $60.72 \pm 2.51^{\mathrm{abc}}$ & $62.41 \pm 2.38^{\mathrm{ab}}$ & $54.97 \pm 1.32^{\mathrm{bc}}$ & $53.37 \pm 2.43^{\mathrm{c}}$ \\
$4^{\text {th }}$ & $88.23 \pm 7.31$ & $86.50 \pm 6.51$ & $86.56 \pm 5.87$ & $86.27 \pm 6.25$ & $76.15 \pm 4.95$ & $74.68 \pm 3.37$ \\
$5^{\text {th }}$ & $137.92 \pm 5.94$ & $136.88 \pm 5.46$ & $135.10 \pm 2.02$ & $134.63 \pm 3.45$ & $129.09 \pm 4.42$ & $127.72 \pm 5.64$ \\
$6^{\text {th }}$ & $149.89 \pm 8.17$ & $149.43 \pm 4.80$ & $151.25 \pm 4.02$ & $146.75 \pm 5.19$ & $144.30 \pm 3.76$ & $143.73 \pm 2.63$ \\
\hline
\end{tabular}

Means bearing different superscript $(a, b, c)$ in a row differ significantly $(p<0.05)$. TDLM=Tithonia diversifolia leaf meal

Table-3: ADG in body weight ( $\mathrm{g} /$ bird) in broiler fed TDLM.

\begin{tabular}{lcccccc}
\hline Age & TDLM-0 & TDLM-2 & TDLM-4 & TDLM-6 & TDLM-8 \\
\hline $1^{\text {st }}$ & $9.96^{\mathrm{a}} \pm 0.21$ & $9.45^{\mathrm{a}} \pm 0.24$ & $8.67^{\mathrm{b}} \pm 0.23$ & $7.99^{\mathrm{c}} \pm 0.28$ & $6.18^{\mathrm{d}} \pm 0.20$ & $5.12^{\mathrm{e}} \pm 0.25$ \\
$2^{\text {nd }}$ & $35.74^{\mathrm{a}} \pm 1.07$ & $35.60^{\mathrm{a}} \pm 1.13$ & $33.92^{\mathrm{a}} \pm 1.06$ & $26.43^{\mathrm{b}} \pm 0.88$ & $19.57^{\mathrm{c}} \pm 1.05^{\mathrm{a}}$ & $15.68^{\mathrm{d}} \pm 0.72$ \\
$3^{\text {rd }}$ & $54.43^{\mathrm{a}} \pm 1.24$ & $52.24^{\mathrm{ab}} \pm 0.90$ & $50.94^{\mathrm{b}} \pm 0.92$ & $30.74^{\mathrm{c}} \pm 0.98$ & $28.85^{\mathrm{c}} \pm 0.44$ & $20.86^{\mathrm{d}} \pm 0.91$ \\
$4^{\text {th }}$ & $37.00^{\mathrm{a}} \pm 0.87$ & $36.22^{\mathrm{ab}} \pm 0.89$ & $36.21^{\mathrm{ab}} \pm 1.74$ & $32.86^{\mathrm{c}} \pm 1.19$ & $31.91^{\mathrm{b}} \pm 2.64$ & $26.63^{\mathrm{d}} \pm 1.06$ \\
$5^{\text {th }}$ & $39.12^{\mathrm{a}} \pm 0.92$ & $39.01^{\mathrm{a}} \pm 0.94$ & $40.56^{\mathrm{a}} \pm 1.05$ & $31.85^{\mathrm{b}} \pm 0.90$ & $35.31^{\mathrm{c}} \pm 1.30$ & $32.07^{\mathrm{b}} \pm 1.37$ \\
$6^{\text {th }}$ & $46.67^{\mathrm{ab}} \pm 1.63$ & $46.26^{\mathrm{ab}} \pm 1.22$ & $48.54^{\mathrm{a}} \pm 0.96$ & $44.29^{\mathrm{bc}} \pm 0.54$ & $41.30^{\mathrm{c}} \pm 0.92$ & $43.71^{\mathrm{bc}} \pm 1.33$ \\
\hline
\end{tabular}

Means bearing different superscripts ( $a, b, c, d, e)$ in a row differ significantly $(p<0.05)$. ADG=Average daily gain, TDLM=Tithonia diversifolia leaf meal

Table-4: Average weekly body weight (g/bird) of broiler fed TDLM incorporated ration.

\begin{tabular}{|c|c|c|c|c|c|c|}
\hline Age & TDLM-0 & TDLM-2 & TDLM-4 & TDLM-6 & TDLM-8 & TDLM-10 \\
\hline & $47.81 \pm 0.32^{\mathrm{NS}}$ & & & & & \\
\hline $7^{\text {th }}$ day & $117.51 \pm 1.77^{a}$ & $113.91 \pm 2.22^{a}$ & $108.29 \pm 1.94^{b}$ & $103.78 \pm 2.26^{b}$ & $91.26 \pm 1.77^{c}$ & $83.76 \pm 2.00^{d}$ \\
\hline $14^{\text {th }}$ day & $367.68 \pm 9.11^{\mathrm{a}}$ & $363.14 \pm 10.04^{a}$ & $345.74 \pm 9.32^{a}$ & $291.01 \pm 7.82^{b}$ & $227.08 \pm 8.78^{c}$ & $3 \pm 6.61^{d}$ \\
\hline $21^{\text {st }}$ day & $753.90 \pm 15.26^{a}$ & $728.85 \pm 15.90^{\mathrm{ab}}$ & $707.55 \pm 12.79^{b}$ & $504.40 \pm 12.94^{c}$ & $429.84 \pm 9.28^{d}$ & $338.49 \pm 12.26^{\mathrm{e}}$ \\
\hline $28^{\text {th }}$ day & $1012.94 \pm 17.05^{a}$ & $982.38 \pm 19.81^{a}$ & $968.63 \pm 22.10^{\mathrm{a}}$ & $867.44 \pm 20.14^{b}$ & 643.55 & $18.63^{d}$ \\
\hline $35^{\text {th }}$ day & $1298.03 \pm 21.01^{a}$ & $1263.19 \pm 13.37^{a}$ & $1252.83 \pm 16.45^{a}$ & 1090.69 & $899.16 \pm 19.74^{c}$ & $748.33 \pm 26.84^{d}$ \\
\hline $42^{\text {nd }}$ day & $1624.72 \pm 30.52^{\mathrm{a}}$ & $1616.66 \pm 17.84^{a}$ & $1592.60 \pm 19.24^{a}$ & $1404.61 \pm 17.76^{b}$ & $1188.29 \pm 17.67^{c}$ & $1054.33 \pm 18.81^{d}$ \\
\hline
\end{tabular}

Means bearing different superscripts $(a, b, c, d, e)$ in a row differ significantly $(p<0.05)$. TDLM=Tithonia diversifolia leaf meal 
Table-5: Nutrient digestibility (\%) in broiler fed TDLM incorporated rations.

\begin{tabular}{lcccccc}
\hline Nutrient & TDLM-0 & TDLM-2 & TDLM-4 & TDLM-6 & TDLM-8 & TDLM-10 \\
\hline DM & $73.88 \pm 0.83^{\mathrm{a}}$ & $70.47 \pm 0.67^{\mathrm{ab}}$ & $67.99 \pm 1.06^{\mathrm{abc}}$ & $64.68 \pm 3.31^{\mathrm{bc}}$ & $62.08 \pm 3.02^{\mathrm{c}}$ & $61.64 \pm 3.11^{\mathrm{c}}$ \\
CP & $65.89 \pm 0.05^{\mathrm{a}}$ & $63.53 \pm 1.04^{\mathrm{ab}}$ & $62.28 \pm 1.62^{\mathrm{ab}}$ & $59.43 \pm 0.21^{\mathrm{b}}$ & $53.51 \pm 2.12^{\mathrm{c}}$ & $53.53 \pm 2.33^{\mathrm{c}}$ \\
EE & $61.40 \pm 0.49^{\mathrm{a}}$ & $54.63 \pm 4.23^{\mathrm{abc}}$ & $58.68 \pm 1.13^{\mathrm{ab}}$ & $60.83 \pm 0.56^{\mathrm{a}}$ & $52.34 \pm 2.36^{\mathrm{bc}}$ & $49.46 \pm 1.21^{\mathrm{c}}$ \\
CF & $44.16 \pm 1.81^{\mathrm{a}}$ & $43.92 \pm 3.40$ & $42.98 \pm 2.71$ & $43.86 \pm 1.52$ & $43.65 \pm 2.23$ & $43.11 \pm 2.67$ \\
NFE & $82.09 \pm 0.51^{\mathrm{a}}$ & $76.84 \pm 0.13^{\mathrm{ab}}$ & $73.75 \pm 0.35^{\mathrm{b}}$ & $70.13 \pm 4.60^{\mathrm{b}}$ & $69.78 \pm 2.19^{\mathrm{b}}$ & $69.36 \pm 2.41^{\mathrm{b}}$
\end{tabular}

Means bearing different superscripts in a row differ significantly $(p<0.05)$. TDLM=Tithonia diversifolia leaf meal, DM=Dry matter, $\mathrm{CP}=$ Crude protein, $\mathrm{EE}=$ Ether extract, $\mathrm{CF}=$ Crude fiber, NFE=Nitrogen free extract

\section{Mortality}

No mortality was recorded up to $8 \%$ TDLM inclusion level, but one bird died (3.13\% mortality) in TDLM-10. However, on post-mortem examination, no significant lesions were noticed in spleen, liver, and kidneys. This might be indication that death might not be for toxic effects of TDLM.

\section{Feed conversion ratio (FCR)}

The mean FCR at $42^{\text {nd }}$ day of age was estimated as $2.17 \pm 0.15, \quad 2.17 \pm 0.15, \quad 2.13 \pm 0.13$, $2.46 \pm 0.16,2.66 \pm 0.11$, and $3.96 \pm 0.10$, respectively, for TDLM-0, TDLM-2, TDLM-4, TDLM-6, TDLM8 , and TDLM-10. During the $1^{\text {st }}$ to $6^{\text {th }}$ week, the FCR decreased with increased inclusion level of TDLM. However, there was no significant difference up to $4 \%$ TDLM inclusion level. Decreasing trend in FCR might be for reduced body weight gain due to decreased digestibility of nutrients for inclusion of TDLM. Prince et al. [23] also observed depression in growth rates of chicks when fed diet containing high tannin sorghum.

\section{Conclusion}

It was concluded from the findings of this study that TDLM could be incorporated up to $4 \%$ level without any adverse effects on growth performance, nutrient utilization, and feed conversion efficiency of broilers reared under deep litter system of management in Mizoram.

\section{Authors' Contributions}

The study was designed and carried out by RB as a part of an Intramural Research project financed by Central Agricultural University, Imphal, Manipur, India. RB drafted, revised and approved the final manuscript.

\section{Acknowledgments}

The author is thankful to the Vice-Chancellor, Central Agricultural University, Imphal, Manipur, India, for providing financial support and necessary facilities for conducting the study successfully.

\section{Competing Interests} interests.

The authors declare that they have no competing

\section{References}

1. Abu, O.A., Olaleru, I.F. and Omojola, A.B. (2015) Carcass characteristics and meat quality of broilers fed cassava peel and leaf meals as replacements for maize and soyabean meal. J. Agric. Vet. Sci., 8(3): 41-46.
2. Adeyemo, I.A. and Sani, A. (2013) Physical appearance and organoleptic properties of poultry meat fed Aspergillus niger hydrolyzed cassava peel meal based diet. Int. J. Agric. Policy Res., 1(6): 166-171.

3. Teye, M., Apori, S.O. and Ayeida, A.A. (2015) Carcass parameters and sensory characteristics of broiler chicken fed diets containing palm (Elaeis guineensis) kernel oil residue. Int. J. Curr. Microbiol. Appl. Sci., 4(6): 1030-1038.

4. Bolu, S.A., Ojo, V., Oyeleke, B.A., Ajiboye, A.O., Baa Sambo, A. and Oluyemi, O. (2009) Effects of Alphamune G on the performance, blood chemistry and histology of broilers. Int. J. Poult. Sci., 8: 32-34.

5. Buragohain, R. (2013) Rations for pigs with unconventional feedstuffs under rural production System in Mizoram. Indian Vet. J., 90(4): 59-63.

6. Sawmliana, M. (2013) The Book of Mizoram Plants (Includes wild Animals, Birds Etc.). $2^{\text {nd }}$ ed. P. Zakhuma, Chanmari West, Aizawl, Mizoram. p252.

7. Ewan, R.C. (1989) Predicting the energy utilization of diets and feed ingredients by pigs. In: Van der Honing, Y. and Close, W.H., editors. Energy Metabolism, European Association of Animal Production, Bulletin No.43. Pudoc Wageningen, Netherlands, p271-274.

8. Buragohain, R. (2013) Nutritive and non-nutritive composition of wild sunflower (Tithonia diversifolia). Indian Vet. J., 90(5): 106-109.

9. Ekeocha, A.H. (2012) Utilization of Mexican sunflower (Tithonia Diversifolia, Hemsley. A. Gray) leaf meal on the average production cost and returns of broiler chicks. J. Rec. Adv. Agric., 1(2): 34-42.

10. Ekeocha, A.H. and Afolabi, K.D. (2012) Carcass characteristics of broilers fed Mexican sunflower (Tithonia diversifolia) leaf meal-based diets. J. Anim. Prod. Adv., 2(5): 271-276.

11. BIS. (2002) Nutrient Requirements of Poultry. Bureau of Indian Standard, Manak Bhavan, 9 Bahadur Shah Zafar Marg, New Delhi, India.

12. AOAC. (2006) Official Methods of Analysis. $18^{\text {th }}$ ed., Vol. I. Association of Official Analytical Chemists, Arlington, VA.

13. Talapatra, S.K., Ray, S.C. and Sen, K.C. (1940). Estimation of $\mathrm{P}, \mathrm{Cl}, \mathrm{Ca}, \mathrm{Na}$, and $\mathrm{K}$ in food stuffs. Indian J. Vet. Sci. Anim. Husbandry, 10: 243-246.

14. Makkar, H.P.S., Bluemmel, M., Borowy, N.K. and Becker, K. (1993) Gravimetric determination of tannins and their correlations with chemical and protein precipitation methods. J. Sci. Food Agric., 61: 161-165.

15. Porter, L.J., Hrstich, L.N. and Chan, B.G. (1986) The conversion of procyanidins and prodelphinidins to cyaniding and delphinidin. Phytochemistry, 25: 223-230.

16. Snedecor, G.W. and Cochran, W.G. (1994) Statistical Method. Oxford and IBH Pub., Co., New Delhi.

17. Odunsi, A.A., Farinu, G.O., Akinola, J.O. and Togun, V.A. (1999) Growth, carcass characteristics and body composition of broiler chicken fed wild sunflower (Tithonia diversifolia) forage meal. Trop. Anim. Prod. Invest., 2: 205-211.

18. Togun, V.A., Farinu, G.O. and Olabanji, R.O. (2006) Feeding graded levels of wild sunflower (Tithonia diversifolia Hemsl. A. Gray) meal in replacement of maize at pre-pubertal age, negatively impacts on growth and 
morphormetric characteristics of the genitalia of Anak 2000 broiler cooks at their pubertal age. World Appl. Sci. J., 1(2): 115-121.

19. Kass, M.L., Van Soest, P.J., Pond, W.G., Lewis, B. and Mc Dowell, R.E. (1980) Utilization of dietary fibre from alfalfa by growing swine. 1. Apparent digestibility of diet components in specific segments of the gastrointestinal tract. J. Anim. Sci., 50: 175-191.

20. Akinmutimi, A.H., Ojewola, G.C., Abasiekong, S.F. and Onwudike, O.C. (2008) Evaluation of toasted, cooked and Akanwu-cooked sword bean meal in place of soya bean meal in broiler starter diets. Int. J. Poult. Sci., 7(5): 480-486.
21. Obun, C.O. (2013) Impact of raw tallow Detarium microcarpum (Guill and Sperr) seed meal on performance and blood parameters in broilers. Iran. J. Appl. Anim. Sci., 3(2): 289-294.

22. Helsper, J.P., Hoogenidjk, F.G., Van Norel, J.M. and Burger, M.K. (1993) Anti-nutritional factors in faba bean (Vicia Taba L.) as affected by breeding towards the absence of condensed tannins. J. Agric. Food Chem., 41(7): 1058-1061.

23. Prince, M.L., Butler, L.G., Roger, J.G. and Featherstone, W.R. (1980) Overcoming the nutritional harmful effects of tannin in sorghum grain by treatment with inexpensive chemicals. J. Agric. Food Chem., 27: 441-445.

$* * * * * * * *$ 